\title{
The effect of competency management on organizational performance through supply chain integration and quality
}

\author{
Zeplin Jiwa Husada Tarigan $^{a^{*}}$, Jenny Mochtar ${ }^{b^{*}}$, Sautma Ronni Basana $^{c}$ and Hotlan Siagiana
}

${ }^{a}$ Master Management, Petra Christian University, Siwalankerto 121-131, Surabaya, Indonesia ${ }^{b}$ English Department, Petra Christian University, Siwalankerto 121-131, Surabaya, Indonesia ${ }^{c}$ Finance Program, Petra Christian University, Siwalankerto 121-131, Surabaya, Indonesia

\section{H R O N I C L E}

Article history:

Received November 6, 2020

Received in revised format

January, 25, 2021

Accepted March 82021

Available online

March 82021

Keywords:

Competency manager

Supply chain integration and

quality

Production capability

Performance

\section{A B S T R A C T}

\begin{abstract}
Synergy is built by manufacturing companies with suppliers and customers in the supply chain to improve organization performance. The research provides simultaneous testing of competency management, supply chain integration, supply chain quality, operational capability as a strategy to improve company performance. Collecting data for medium and large manufacturing companies in Indonesia are performed by sending a questionnaire link via email and WhatsApp. 625 respondents received the questionnaires and 152 respondents filled them with a response rate of $24.32 \%$. Data analysis were performed using partial least squares to test the hypotheses and found that competency management had a direct impact on supply chain integration (0.598), supply chain quality $(0.387)$ and operational capability $(0.346)$. Supply chain integration affects increasing supply chain quality (0.428), operational capability (0.619) and organizational performance $(0.255)$. Supply chain quality impacts increasing operational capability $(0.260)$ and does not significantly affect organizational performance $(0.018)$. The operational capability of a manufacturing company has an impact on improving organizational performance $(0.584)$. Practical contribution is that managers who manage the supply chain must continue to enhance skills and knowledge and supply chain components in quality for increased performance.
\end{abstract}

(C) 2021 by the authors; license Growing Science, Canada.

\section{Introduction}

Manufacturing companies must be able to build competitiveness by creating their own strategies and they must create a company's uniqueness compared to other companies as the company's competitors (Tarigan \& Siagian, 2021). The competitiveness built by the manufacturing industry requires an increase in its operational performance (Doan, 2020). The current era of disruption has put pressure on manufacturing companies to build integration with suppliers and customers in the face of an uncertain environmental change. The differences between countries result in uncertainty in supply chain integration, which impacts flexibility performance and has no impact on financial performance (Liu et al., 2021). The manufacturing industry is expected to build integration with suppliers and customers easily and quickly. The integration that occurs within the company can support the company's external integration. Internal integration and external integration are called supply chain integration (Sundram et al., 2018). The manufacturing industry can collaborate with partner companies and will provide benefits for the balance of supply and demand (Tarigan \& Siagian, 2021). External integration with customers will affect organizational performance, among others, can produce product quality, increase service levels, respond to customer needs more quickly, and anticipate changing customer needs and wants (Huo et al., 2014). The results of integration with customers will make it easier for internal managers to coordinate with all functions. Cross-functional related to suppliers can integrate to provide fast information. Suppliers' information regarding product criteria and production schedules makes it easier for suppliers to provide raw material according to the specified lead time. Managers' ability to build integration with intra-organization and extra-organization can produce excellent quality performance (Soares

* Corresponding author

E-mail address: zeplin@petra.ac.id (Z. J. H. Tarigan)

C 2021 by the authors; licensee Growing Science. doi: $10.5267 /$ j.uscm.2021.3.004 
et al., 2017). The ability to collaborate with suppliers provides timely delivery of raw materials and the quality of raw materials needed. Company integration with suppliers can provide quality material flow from suppliers to customers in the supply chain flow, which is called supply chain quality management (Prashar and Aggarwal, 2020; Gunasekaran et al., 2019). The flow of quality material conforms with applicable specifications and standards. The quality of raw material is suitable for use and can satisfy customer wants, needs and expectations at a competitive cost. Supply chain quality can create value for customers, increasing satisfaction and increasing its market (Alkalha et al., 2019). The quality problem in the company if it is unable to fulfil the customer's wishes has an impact on the product is returned by the customer, will delay the completion of the product in the production, reduction price that occurs to the customer and allows a penalty from the customer (Prashar \& Aggarwal, 2020). The quality of products delivered to customers is difficult to achieve without ensuring the quality of the production process is not completed in the process. Quality in the process is difficult to achieve if the raw material provided does not meet the specified specifications' requirements and without strong support from the company organization (Yu \& Huo, 2018). The quality of the material obtained from the supplier results from the supplier's commitment to meeting the company's specifications. Supply chain capability can increase organization capability so that it increases company performance (Rajaguru \& Matanda, 2019).

Organization capability can increase output by reducing input transformation to impact supply chain integration (Huo, 2012; Yu et al., 2018). Quality control in the supply chain flow is an appropriate organizational commitment with adequate manager competence (Hohenstein et al., 2014). Strong manager competencies will empower employees to support the work effectiveness set by the organization (Ekaterini, 2011). Capabilities based on company resources help integrate various internal functional areas within the organization to increase efficiency and reduce waste (Yu et al., 2014). Internal integration within the function will coordinate with external parties to synchronize the process with members of the downstream and upstream supply chains (Tan \& Cross, 2012). Supply chain quality management describes a company's ability to improve product quality by integrating upstream and downstream in improving organizational performance (Cogollo-Flórez \& Correa-Espinal, 2019). Competency managers in supply chain management are prioritized to understand and know the supply chain concept (Flöthmann, Hoberg, Wieland, 2014; Azadegan, 2011). Competency managers owned by companies at the middle level must be adjusted to the needs of changing globalization (Ekaterini, 2011). Supply chains are managed with various countries and between countries, so that it needs to be aligned and coordinated in its application with integrated technology 4.0 (Liboni et al., 2019). Companies have people who are capable and expert in building supply chain systems that have an impact on the supply chain integration system. The company's supply chain integration will provide work effectiveness for company operations (Tarigan et al., 2019b). Supply chain integration consisting of internal integration and external integration is related to performance (Fernandez \& Jiménez, 2017). Supply chain integration is a strategy for companies in improving company performance and company competitiveness (Kanyoma et al., 2018). Supply chain integration can maximize the efficiency of the flow of goods, exchange information, share resources to increase mutual benefits (Wang et al., 2016). Supply chain integration makes it easier for companies to consistently adjust market needs with operation capability (Samuelsson et al., 2016; Yu et al., 2015). Manufacturing companies can identify problems in the market today and issues that are potential ones that will come. This condition makes it easier for companies to define strategies and steps to suit their capabilities (Yu et al., 2018; Hwang \& Min, 2015). The company's production capability determines the size of the sampling lot received from suppliers and is adjusted to the production capacity. The company's production results with lot size are adjusted to customers' delivery capacity to reach an optimal point (Hsu et al., 2020). Supply chain integration and supply chain capability can improve operational performance and competitive performance (Rajaguru \& Matanda, 2019; Doan, 2020). Supply chain integration enhances close partnerships with suppliers and customers. The company's ability to increase collaboration in the supply chain improves operational performance. This research emphasizes manufacturing companies in Indonesia that are still focused on emphasizing product quality independently, without involving partners. Based on the explanation above, it is found that many researchers are still testing the relationship between the two concepts and three concepts. There has not been a simultaneous test of supply chain quality management, competency managers, supply chain integration, operation capability and organization performance.

\section{Literature Review}

\subsection{Supply Chain Quality Management}

The company can build relationships with a system approach in providing quality products for customers by producing quality raw materials from suppliers (Prashar \& Aggarwal, 2020). Supply chain quality management can be integrated and linked by coordinating with external parties by involving many agents in the supply chain flow to support the overall supply chain performance (Cogollo-Flórez \& Correa-Espinal, 2019). The ability of managers in the company to build effective relationships between internal companies and suppliers and customers smoothly in the supply chain flow to produce quality performance simultaneously is the goal of all parties (Soares et al., 2017). Companies' quality of products can no longer be done independently but must involve external parties of the company (Mabrouk, 2020). Customer involvement from external to the company can provide information about the required product criteria (Hong et al., 2019). Upstream quality involvement is suppliers' involvement in supplying quality raw materials according to the organization's standards (Alkalha et al., 2019). The relationship between intra-organizational and extra-organizational communication, coordination, and collaboration involving commitment and management leadership that focuses on quality is called supply chain quality 
management (Fernandes et al., 2017). Supply chain quality is a relationship built internally by the company with external companies to collaborate in managing the quality of a product or service with a high level of quality (Yu \& Huo, 2018). The indicators used to measure supply chain quality are: the company and partners are jointly implementing the quality system properly, each member in the supply chain flow helps each other in solving quality problems, the company has documents that ensure that the products produced are of high quality, all components in supply chain flow is responsible for the quality delivered, all members are actively committed to improving the quality of the products made.

\subsection{Supply Chain Integration}

Supply chain integration improves a company's ability to coordinate upstream and downstream (Fernandez \& Jiménez, 2017). Integration in the supply chain with four areas covering flow (physical, information, financial), processes and activities, technology and systems, and integration of actors (structure and organization). Companies use information technology in the form of enterprise resources planning on supply chain integration (Hwang \& Min, 2015). Integration using information technology can facilitate information exchange across functional boundaries within companies and between companies (Huo, 2012). Supply Chain integration increases company complexity if the complexity of supply is high, and the influence on the integration itself is minimal. It cannot be detected if the level of complexity reaches a low level. In an environment with high supply chain integration complexity, companies use structured communication to achieve supply chain integration, which negatively affects cost performance (Gimenez, Vaart, Donk, 2012). When building external integration, companies' obstacles are the partners worried that the information they have can leak to their company's competitors, for example, the amount of inventory they have, which can hinder their operational processes (Kanyoma et al., 2018). Supply chain integration between companies and suppliers and customers will facilitate the transfer of knowledge so that it is easy to adapt and change according to market developments (Alkalha et al., 2019). Supply chain integration is the most effective way to increase SCM efficiency, increase company competitiveness, reduce transaction costs, improve supply chains, and strengthen and improve company performance (Wang et al., 2016). The indicators used to measure supply chain integration are sharing internal and external company information in making decisions, sharing forecasting with partners and strategic partnerships in collaboration with partners.

\subsection{Manager competencies}

The management of the supply chain in a company requires experts in managing the business to be more effective and efficient with the company's internal and external coordination (Ellinger \& Elinger, 2014). Companies need manager competence to stay competitive in competition. This condition requires strong collaboration between the SCM department and the HRM (human resources management) department to increase competence in understanding essential skills, knowledge gaps, and training needs (Liboni et al., 2019). The competence that is possessed as an expert in supply chain managers to carry out work effectively to increase its competitiveness includes skills, abilities owned by managers and knowledge retained (Hohenstein et al., 2014). Manager competence is a skill that managers have to communicate to share information with subordinates, superiors, and collaborators. Having, influencing, and changing implementation skills will also help identify problems and solutions to develop an effective supply chain (Ellinger \& Elinger, 2014). Key user empowerment in manufacturing companies needs to be designed to improve their competencies (Tarigan et al., 2019a). Subjective and objective assessments can measure the measurement of manager competence. Subjective judgments can be in the form of relative thoughts, results from guesswork, and feelings. Meanwhile, the objective is a more certain attitude; its validity can be believed and proven based on facts/data. An objective perspective is an attitude that is needed for a manager in dealing with problems. However, it is difficult to recruit managers with high competence according to objective criteria from the study results. Companies need to work harder in preparing selection applications to suit company needs (Flöthmann et al., 2018). The competence of managers at the middle manager level is divided into five competencies: management effectiveness oriented, integrity oriented, personal work effectiveness oriented, people-oriented, and oriented towards special knowledge (Ekaterini, 2011). The indicators used in the manager competency variable adopt (Flöthmann, Hoberg, Wieland, 2014), namely SCM knowledge, Analytical and problem-solving abilities, Interpersonal skills, Computer / IT skills, Industry experience, General management skills.

\subsection{Operation Capability}

Production capability is the ability of an organization to use the production process to convert inputs into various types of products that are profitable for the organization (Yu et al., 2018). Production capability can be achieved when companies develop and focus on human resources and technology related to production to produce a wide variety of products that meet real customer needs (Samuelsson et al., 2016). The potential for production capabilities to help an organization meet the benefits of an increasingly competitive global environment highlights the need to better understand the relationship between production capability and competitiveness. Production capability is determined by the company's suppliers and customers (Yu \& Ramanathan, 2015). Supplier-buyer partnership is designed to operate an optimal product acceptance plan for all parties (Tarigan and Siagian, 2021; Mabrouk, 2020). As the recipient of material from the supplier, the company has determined the size of the product lot to be inspected, the size of the production process and delivery to the customer (Hsu et al., 2020). Operational capability at companies related to product level characteristic, namely product complexity and product variety, determines internal integration and supplier integration from a governance point of view in a manufacturing 
company (Shou et al., 2017). Production capability is the ability to identify a potential problem and be able to make improvements right away. This ability depends on staff skills, knowledge, experience and independence (Mello et al., 2015). The company's high capability means that the company does not need to worry about providing its products with high quality and on-time (Tan and Cross, 2012). The production capability scope includes the skills and experience required in production and the knowledge needed to understand product drawings and specifications. Therefore, it is necessary to divide the team in creating products according to their respective expertise so that the production process runs precisely and quickly. (Mello et al., 2015). Increased production capability has a competitive advantage over its competitors and increases customers' value (Hwang and Min, 2015; Doan, 2020). The indicators used in operational capability are the ability to determine company planning, select the company's production capacity, determine the company's marketing capacity, assess the use of company resources, and the ability to determine the company's production costs.

\subsection{Organizational Performance}

Organizational performance is a fundamental problem for every organization, both profit and non-profit organizations. It is one factor that determines the success or failure of an organization (Yu and Huo, 2018; Huo et al., 2014). Organizational performance is often associated with organizational strategy (Hani, 2021). Organizational performance is always planned and controlled to improve organizational strategy (Tarigan \& Siagian, 2021). The main focus is on organizational performance, but the idea that performance must be predicted, understood, and shaped is commonplace in all fields. Achieving high organizational performance can be done by establishing and focusing on results, empowering its workforce, motivating and inspiring people to succeed, being more flexible and able to adapt to new conditions, being able to compete in terms of performance, maintaining communication with stakeholders, and must be in line with the mission of the organization. Organization performance is an operational capability that a company has combined with the dimensions of company competitiveness obtained from supply chain integration (Rajaguru \& Matanda, 2019; Doan, 2020). Managers need to know the factors that affect organizational performance to initiate good organizational performance to achieve goals. Managers need to define, conceptualize, and measure performance even though this is quite difficult to do (Abu-Jarad, Yusof, \& Nikbin, 2010). Company performance is its ability to achieve its goals by using resources effectively and efficiently (Hong et al., 2019). Rajaguru and Matanda (2019) measure operational performance: which is fulfilling requirements, responding to changes to market demand, effectiveness in on-time delivery, reduction in lead time to fulfil customers' orders, effectiveness in delivering reliable quality products, reduction in cost to reach Customers, reduction in overhead costs and reduction in inventory costs. Operational performance is measured by customer service level, overall product quality, product support, delivery dependability, pre-sale customer service, delivery speed and volume flexibility (Yu \& Huo, 2018; Huo et al., 2014). Measurement items used in organization performance focused on measuring operational performance are product quality, fulfilling requirements, customer satisfaction, delivery time, and flexibility.

\section{Relationship Between Concepts}

\subsection{Relationship between the Competency Management Concept and SC Integration and SC Quality}

SCM needs to integrate with the manager department's competence because the company will be faced with complex and strategic problems. Therefore, this integration is necessary to create and maintain a competitive advantage by leveraging human resource development's professional expertise. Address development and change issues associated with a critical set of supply chain manager skills currently in short supply (Ellinger \& Elinger, 2014). Planning is the main activity in SCM, so it takes a competent department manager who has excellent expertise in his field to plan the best decisions that the company can take. This decision improves supply chain integration starting from product planning, raw material supply, operations to sales. (Flöthmann et al., 2018). Key user employees can impact process integration and production systems for manufacturing companies (Tarigan et al., 2019a). Qualifications and education possessed by human competencies, including managers, collaboration and integration of supply chain integration, and data and information management, are three different dimensions that are the main factors for the sustainability of a company's supply chain (Liboni et al., 2019). Knowledge Managerial illustrates the need for a dynamic approach concerning network-related routines in supplier relationships in the context of product innovation. Managers must devote the same attention to strengthening existing supplier relationships and initiating new supplier relationships, and managing supplier relationships that are not qualified in their work. This relationship is essential so that in the future, there is good cooperation and work becomes a good result. A dynamic approach to networking with suppliers is vital because it influences product innovation from a company perspective (Mitrega et al., 2017). The capabilities of the manager's impact supply chain integration by accessing, sharing information and creating new knowledge in supply chain members (Azadegan, 2011; Alkalha et al., 2019).

H1: Competency management have an impact on increasing supply chain integration.

$\mathrm{H} 2$ : Competency management have an impact on increasing supply chain quality. 
Operation capability is the company's ability to generate efficiency and flexibility by maximizing company resources or minimizing waste in company operations (Yu et al., 2018). The ability of managers by developing their departments' functional capabilities at 186 retail companies in the UK impacts operational capability and financial performance (Yu et al., 2014). The existence of human resources in an organization is a valuable asset for the organization itself. The success of an organization is determined by the quality of the people who are in it. Managers work optimally if the organization can support progress by seeing the increase in their competencies. The relationship between competency-based performance management and organizational effectiveness is significant. The concept of competency-based performance in organizations is also needed. Key user empowerment provides a positive relationship between competency-based superior performance and organizational effectiveness with productivity, adaptability, and flexibility (Shet et al., 2019; Tarigan et al., 2019a). The company can increase managers' role in transforming inputs into outputs by incoming profiling materials, transformation processes, and outgoing products to increase production capability in mineral, food and steel industries (Samuelsson et al., 2016).

\section{$\mathrm{H}_{3}$ : Competency Management has an impact on operation capability.}

\subsection{The relationship between supply chain integration concept and supply chain quality}

Supply chain integration integrates upstream and downstream in the supply chain flow (Tan \& Cross, 2012; Alkalha et al., 2019). Supply chain integration in manufacturing companies impacts internal quality, supplier quality and customer quality integration by building product or service quality in the supply chain flow (Alkalha et al., 2019). Supply chain integration impacts quality performance in manufacturing companies in Saudi Arabia (Hani, 2021). Collaboration built by the company is integrated with intra-organization and inter-organization by carrying out the communication process, sharing information and sharing knowledge to achieve product or service quality in the supply chain flow according to the requirements set by the customer (Yu \& Huo, 2018). Supply chain integration has a relationship with supply chain quality at customer focus and quality leadership in 325 manufacturing companies in the UK (Soares et al., 2017).

\section{$\mathrm{H}_{4}$ : Supply chain integration has an impact on supply chain quality.}

\subsection{The relationship between the supply chain integration concept and operation capability}

The company seeks to improve efficiency and effectiveness by increasing production output but using relatively the same amount of production input is called production capability (Yu et al., 2018). The company's ability to involve suppliers and customers in the form of integration supports company efficiency (Tarigan et al., 2019b). Supply chain capability is the company's ability to use internal and external resources to produce company performance and competitiveness (Rajaguru and Matanda, 2019). Supply chain integration using enterprise resources planning has impacts the operation capabilities, supplier capabilities and customer value of a company by requiring a robust strategic plan and management commitment (Hwang \& Min, 2015; Tarigan et al., 2019a). The most crucial strategy in a company to strengthen its production capability is to carefully identify the supply chain integration strategy and know the importance of all relationships between parts of its supply chain (Behesti et al., 2014). The practice of supply chain integration, if done internally, will affect external integration (Hani, 2021). These aspects of internal and external supply chain integration are explored further. Company management understands the importance of the two parts of integration, so there will be an increase in its performance and production capability (Siagian et al., 2020). Flexibility is also a significant factor in smooth supply chain integration affecting production capabilities due to direct collaboration and exchange of information between departments to make joint decisions and align incentives (Chaudhuri et al., 2018). Operation capability related to product complexity impacts internal integration and supplier integration but does not affect customer integration. The difference in operation capability in the company's product variety has a positive impact on internal integration, supplier integration, and customer integration (Shou et al., 2017).

\section{$\mathrm{H}_{5}$ : Supply chain integration has an impact on operation capability.}

\subsection{The Relationship between Supply Chain Quality Concept and Operation Capability}

Supply chain quality management is a way to increase company competitiveness. The company can share quality information, collaborate, and collaborate to improve product and service quality in manufacturing companies in China (Hong et al., 2019). Supply chain quality that can provide a sustainable business. Good supply chain quality will have an impact on manufacturing capability (Yu et al., 2014). Manufacturing capability measured using 10 R (refuse, rethink, reduce, reuse, repair, refurbish, remanufacture, repurpose, recycle and recover), impacts sustainable development outcome business (Bag et al., 2021). Supply chain quality has an impact on the company. In producing quality products with minimum waste (Yu et al., 2018).

$\mathrm{H}_{6}$ : Supply chain quality has an impact on operation capability. 
Supply chain integration is an interconnection between companies and intra-organization, and extra-organizations can coordinate and synchronize systems to achieve mutually set goals (Chaudhuri et al., 2018). The effect of supply chain integration on organizational performance shows improvement and technical, operational, and cultural compatibility (Tarigan et al., 2019b). Supply chain integration and my focusing on organizational performance increase supplier capability (Mitrega et al., 2017). Supply chain integration impacts improving operational performance in Saudi manufacturing companies (Hani, 2021). The use of supply chain integration to company performance has a strong relationship and makes the company more operational and competitive (Rajaguru and Matanda, 2019). Supply chain integration that is carried out internally can improve external integration, and internal and external integration can improve company performance (Huo, 2012). Internal integration and process integration impact increasing operational performance on product quality produced and customer service levels in 604 manufacturing companies located in China (Huo et al., 2014). Efficient supply chain integration is very likely to play a more critical role in the continuous improvement of company performance. In contrast, for large companies, there is a close relationship between SCM and competitiveness, which has a significant influence on company performance. Emphasis on supply chain integration.

\section{$\mathrm{H}_{7}$ : Supply chain integration has an impact on organizational performance.}

\subsection{The relationship between the concept of supply chain quality and organizational oerformance}

The company's supply chain quality in an integrated manner by building internal quality integration, supplier quality integration, and customer quality integration can improve operational performance in 308 manufacturing companies in Zhejiang province (Yu \& Huo, 2018). Supply chain quality practices do not impact operational performance due to the low substantive, effective and efficient supply chain practices. The low condition of supply chain quality practices has resulted in a lack of enthusiasm in its implementation because it does not directly impact operational performance in the short term (Hong et al., 2019). Supply chain quality positively impacts improving operational performance related to quality performance and focuses on customers in 325 UK manufacturing companies (Soares et al., 2017).

\section{$\mathrm{H}_{8}$ : Supply chain quality has an impact on organizational performance.}

\subsection{The relationship between operation capability concept and organizational performance}

Optimizing the use of company resources to produce output impacts business performance by increasing productivity and efficiency (Yu et al., 2018). The company's supply chain capability that can integrate with external parties by sharing information and coordination in the supply chain with an excellent response to partners can improve organization performance (Rajaguru \& Matanda, 2019). Superior essential competencies possessed by employees and managers in the company increased productivity, flexibility and adaptability, and organization capability. Increased organization capability has an impact on organization effectiveness (Shet et al., 2019). The operation capability of retail companies in the UK can increase retail efficiency and determine the increase in financial performance (Yu et al., 2014). Company functional capabilities consisting of operation capability and marketing capability provide increased organizational performance, especially in the performance environment in 121 manufacturing companies in the UK. The operation capability shows that manufacturing companies can increase efficiency in the delivery process, reduce production process costs, and increase company competitiveness (Yu et al., 2015).

\section{$\mathrm{H}_{9}$ : Operation capability has an impact on organizational performance.}

\section{Research Methods}

\subsection{The data}

This study took data from manufacturing companies in Indonesia. Manufacturing companies in Indonesia are strategic because they contribute $20 \%$ to the national gross domestic product (GDP) and strengthen Indonesia's position in the world's fifth rank. Manufacturing companies in Indonesia have accommodated many employment opportunities considering that Indonesia's population is the fifth largest in the world. Researchers distribute questionnaires to practitioners of manufacturing companies by sending them via google.form link via WhatsApp, Facebook, email and direct contact. Researchers try to communicate with the questionnaire filler via chat. The researcher carried out the first stage by determining the number of enumerators distributing questionnaires to the manufacturing companies amounting to seventy. This stage aims to communicate in a manner to ensure that those who receive the questionnaire are employees who work at manufacturing companies. In the second stage, the researcher focused on manufacturing companies that have implemented supply chain integration using information technology in enterprise resource planning. Researchers only use respondents who have a workforce of more than 20 because they are included in medium manufacturing companies and have a middle manager's characteristics. The middle manager category determined as a competency management is an employee who has 
a minimum position as a supervisor in his department. The supervisor's responsibilities related to the company's supply chain flow can carry out business processes and control processes in their departments to produce quality products or services. Respondents who filled out the questionnaire on the link amounted to 625 respondents. Researchers in the first stage carried out the editing process to ensure that the manufacturing company had more than 20 employees. The first editing was obtained by manufacturing companies totalling 265 manufacturing companies. The second result of editing was ensuring that the middle manager filled out the questionnaire. The number of questionnaires used for the next process in testing the hypothesis amounted to 153 respondents.

\subsection{Measure}

Measurements in research consisting of variable competency management, supply chain integration, supply chain quality, operation capability and organization performance. Items measurement determined from previous studies that are adjusted to manufacturing conditions in Indonesia. The number of 153 respondents who were accepted and checked initially by paying attention to filling out the questionnaire was following the instructions set. The initial validation results were used to obtain the respondent profile analysis obtained by 153 respondents. The PLS analysis used 151 questionnaires because two respondents did not entirely cover the measurement items. Respondent profiles obtained from the questionnaires' results are shown in Fig. 1, and descriptive analysis and measurement items for each variable are shown in Table 1. Based on the male gender, $59 \%$ and $41 \%$ of women indicate that the majority of men who work in the manufacturing industry are because they still need coordination and control of the condition of floor production with employees. The obtained characteristics based on the respondent's department related to the use of enterprise resources planning and supply chain software are marketing (29\%), production (27\%), finance and accounting (14\%), planning (10\%), purchasing $(9 \%)$, warehouse $(8 \%)$ and information technology $3(\%)$. Based on department analysis, the implementation of the company's supply chain involves all related departments to focus on the efficiency and effectiveness of the manufacturing company business processes. The characteristics based on the position of the company are obtained by supervisor (14\%), manager (57\%), general manager/director $(13 \%)$ and CEO / owner (16\%). The position responsible for supply chain implementation in the largest companies is in the managerial position. $29 \%$ of the top management also played an active role in controlling supply chain implementation in manufacturing companies. Competency managers in implementing supply chains based on profile have sufficient capabilities.

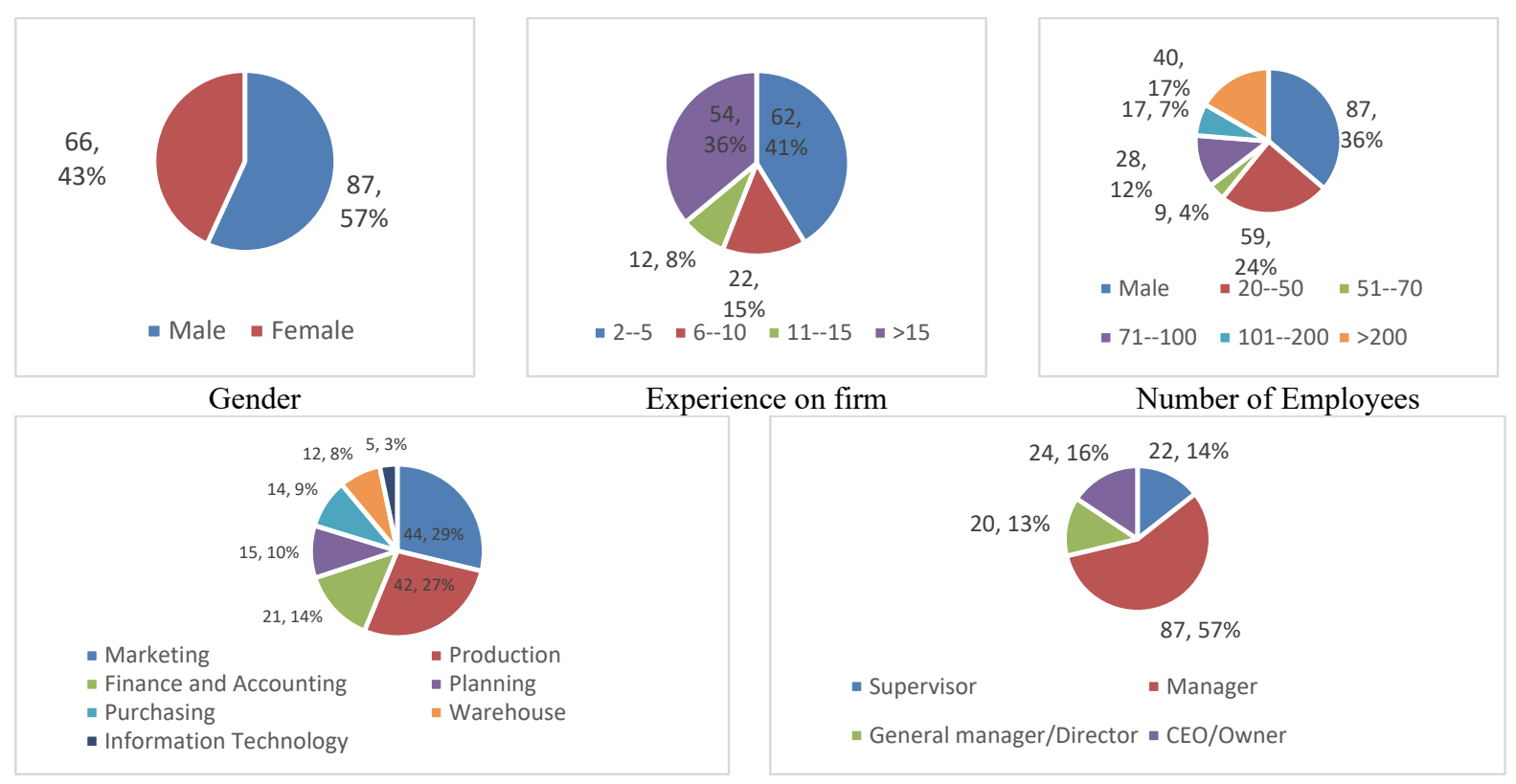

Department

Fig. 1. Characteristics of Respondent Profile

Respondent profiles based on experience with long working in the company were obtained 2 years- 5 years (41\%), 6 years - 10 years $(14 \%), 11$ years -15 years $(10 \%)$ and above 15 years $(35 \%)$. The profile based on the length of work shows that you have adequate experience and understand the work in detail on a manufacturing company's production floor. 59\% of respondents have shown that they have worked at least above 6 years, indicating that they already know the supply chain's implementation and have adequate competence in managing resources. Profile of respondents based on the number of employees obtained 20-50 employees (39\%), 51-70 employees (6\%), 71-100 employees (18\%), 101-200 employees (11\%) and Above 200 employees (26\%). The manufacturing companies still rely on labor and are not fully automatic in the production area due to affordable labor costs. Testing the fit model's goodness for all item measurement obtained on Table 1 , the first composite reliability value on the competency management variable $(0.924)$ and validity test with the lowest loading factor with items supply chain knowledge (0.742). Second, the variable Supply chain integration $(0.820)$ and lowest 
loading factor of items joint decision making (0630), the third supply chain quality $(0.781)$ and the lowest loading factor on the item responsible for the quality of the output (0513). Fourth, the variable operation capability (0.814) and the lowest loading factor on the company's production cost item (0.588), the last and fifth variable is Organization performance (0.900), and the lowest loading factor is the customer satisfaction (0.682). Based on the results of the analysis of the composite reliability value, loading factor and AVE, it is said to have met the predetermined requirements so that the goodness of fit model can be well received.

Table 1

The goodness of Fit Model

\begin{tabular}{|c|c|c|c|c|}
\hline Item Measurement & $\begin{array}{c}\text { Cross } \\
\text { Loading }\end{array}$ & $\begin{array}{l}\text { Composite } \\
\text { Reliability }\end{array}$ & AVE & Mean \\
\hline Competency Manager & & 0.924 & 0.818 & 4.5033 \\
\hline Supply chain knowledge & 0.742 & & & 4.5400 \\
\hline Analytical and problem-solving ability & 0.776 & & & 4.4200 \\
\hline Interpersonal skills & 0.873 & & & 4.5333 \\
\hline Computer / IT skills & 0.896 & & & 4.4733 \\
\hline Industry experience & 0.806 & & & 4.4867 \\
\hline General management skills & 0.807 & & & 4.5667 \\
\hline Supply chain integration & & 0.820 & 0.649 & 4.3500 \\
\hline Sharing information & 0.823 & & & 4.3400 \\
\hline Joint decision making & 0.630 & & & 4.0667 \\
\hline Sharing forecasting & 0.766 & & & 4.4133 \\
\hline Collaboration with partners & 0.691 & & & 4.5800 \\
\hline Supply chain quality & & 0.781 & 0.731 & 4.0907 \\
\hline Together implement a good quality system. & 0.746 & & & 4.4467 \\
\hline Helping each other in solving quality problems. & 0.697 & & & 4.2667 \\
\hline Having documents that guarantee that the products produced are of high quality. & 0.694 & & & 4.2800 \\
\hline Responsible for the quality produced. & 0.513 & & & 3.4467 \\
\hline Committed to improving the quality of the products produced. & 0.565 & & & 4.0133 \\
\hline Operation capability & & 0.814 & 0.693 & 4.1053 \\
\hline Company planning & 0.797 & & & 4.2067 \\
\hline Company production capacity & 0.819 & & & 4.1867 \\
\hline Company marketing capacity & 0.788 & & & 3.3800 \\
\hline Use of company resources. & 0.765 & & & 4.5333 \\
\hline Company production costs & 0.588 & & & 4.2200 \\
\hline Organization Performance & & 0.900 & 0.806 & 4.1933 \\
\hline Product & 0.827 & & & 4.4267 \\
\hline Quality Fulfilling requirement & 0.841 & & & 4.3467 \\
\hline Customer satisfaction & 0.682 & & & 3.9733 \\
\hline Delivery time & 0.865 & & & 4.0667 \\
\hline Flexibility & 0.788 & & & 4.1533 \\
\hline
\end{tabular}

The analysis results show that the average value of the questionnaire statements on each measurement item is shown in Table 1. The average value of competency management is (4.5033) which indicates that the management competence of the manufacturing company is currently excellent. The competency management that is owned is adequate with general management skills (4.5667), and supply chain knowledge (4.5400) are categorized as very good. Study the mean variable supply chain integration (4.5300), which illustrates that the company has integrated internally and externally with partners. Supply chain integration has been carried out very well, shown by collaboration with partners (4.5800) in solving problems on the production floor and sharing forecasting (4.4133) carried out by manufacturing companies with suppliers and customers. The implementation of supply chain quality (4.0907) is adequate for manufacturing companies to maintain product and service quality. The supply chain quality with the lowest average value on the items is responsible for the quality produced (3.4467), and the highest is for implementing the quality system well (4.4467). The quality of manufacturing companies' quality still shows that suppliers, manufacturers, and customers have a suitable and adequate quality system implementation. Different things happen when the quality supply chain system is run together in the supply chain flow. Suppliers, manufacturers and customers prioritize individual interests simultaneously. A review of operation capability (4.1053) shows that the manufacturing company already has an adequate operation system, with the highest value on the use of company resources (4.5333) and the lowest value on the company's marketing capacity (3.3800). The company's marketing conditions had the lowest score during the COVID-19 period. Researchers distributed research questionnaires from February 2020 to October 2020, which showed that manufacturing companies' products were only absorbed in the domestic market by $48 \%$ due to international product restrictions. The last variable is organization performance (4.1933), with the highest item on product quality (4.4267) and fulfilling requirements (4.3467). The manufacturing company's product and service results have met the customer's needs adequately by providing quality product according to the specified specifications.

\section{Results, Discussion, and Implication}

\subsection{Results}

The results of data processing using partial least squares are shown in Fig. 1 and Table 2. 


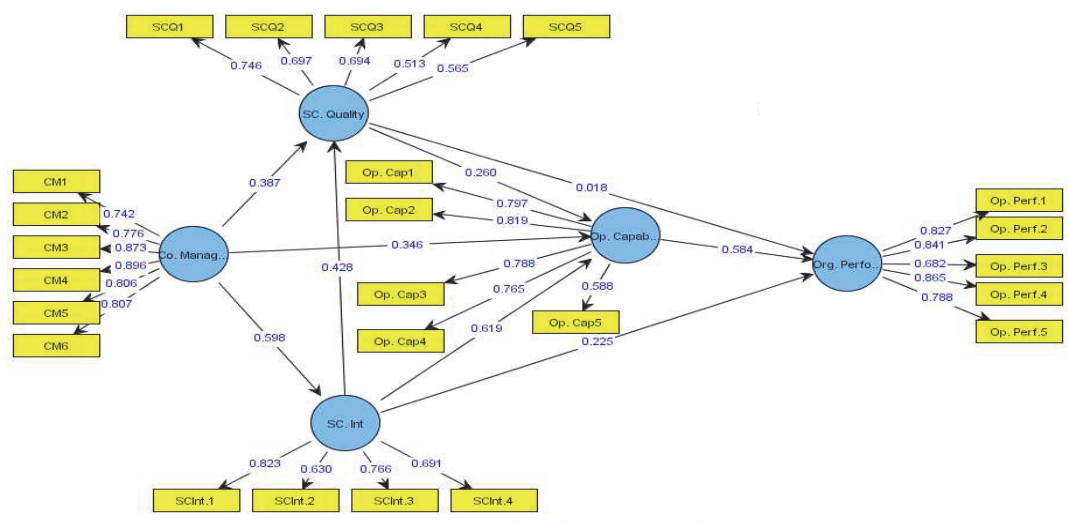

Fig. 1. The Result of Path Coefficient

Based on the results of the partial least squares in Fig. 1 and Table 2, it is found that the direct influence of the variables between the two research concepts is the answer to the nine research hypotheses. The first hypothesis set is that competency management affects supply chain integration with a path coefficient of 0.598 and a t-statistic (9.754> 1.96). The first hypothesis results are accepted, and the same is done for the relationship between one variable and another. The accepted hypothesis is the second hypothesis which states that competency management affects the supply chain quality of 0.387 . The third hypothesis is accepted so that the competency management affects the operation capability of 0.346 . The fourth hypothesis is accepted, so supply chain integration affects supply chain quality by 0.428 . The fifth hypothesis, which states that supply chain integration affects operation capability is acceptable. The supply chain integration with internal and external integration can increase the company's operation capability in the effective and efficient use of resources. The sixth hypothesis states that supply chain quality affects increasing operation capability by 0.260 . This condition illustrates that suppliers, manufacturers and customers maintain product quality according to the required specifications and help each other.

Table 2

Path Coefficient

\begin{tabular}{|c|c|c|c|c|}
\hline Direct Effect & $\begin{array}{l}\text { original sample } \\
\text { estimate }\end{array}$ & $\begin{array}{c}\text { mean of } \\
\text { subsamples }\end{array}$ & $\begin{array}{l}\text { Standard } \\
\text { deviation }\end{array}$ & T-Statistic \\
\hline Co. Management $\rightarrow$ SC. Int & 0.598 & 0.613 & 0.061 & 9,754 \\
\hline Co. Management $\rightarrow$ SC. Quality & 0.387 & 0.383 & 0.073 & 5.311 \\
\hline Co. Management $\rightarrow$ Op. Capability & 0.346 & 0.354 & 0.13 & 2.639 \\
\hline SC. Int $\rightarrow$ SC. Quality & 0.428 & 0.437 & 0.065 & 6.564 \\
\hline SC. Int $\rightarrow$ Op. Capability & 0.619 & 0.605 & 0.107 & 5.767 \\
\hline SC. Quality $\rightarrow$ Op. Capability & 0.260 & 0.261 & 0.09 & 2.885 \\
\hline SC. Int $\rightarrow$ Org. Performance & 0.225 & 0.227 & 0.105 & 2.157 \\
\hline SC. Quality $\rightarrow$ Org. Performance & 0.018 & 0.031 & 0.078 & 0.229 \\
\hline Op. Capability $\rightarrow$ Org. Performance & 0.584 & 0.579 & 0.086 & 6.823 \\
\hline
\end{tabular}

The seventh hypothesis is that supply chain integration affects increasing organization performance by 0.225 . The integration that the company builds internally and integrates with external parties can meet customer needs. The eighth hypothesis shows that supply chain quality does not significantly affect operational performance, where the t-statistic $(0.229$ $<1.96$ ) does not meet the requirements. The Supply chain quality set at manufacturing companies has not directly impacted organizational performance because suppliers, manufacturers, and customers are still running independently. Supply chain quality that involves the three party's supplier, manufacture and customer has not collaborated and is always something new for practitioners. The operational capability of the company has a significant impact on organization performance with a magnitude of 0.584 . A manufacturing company's ability to increase adequate resources and good company planning can improve organization performance to produce quality products and fulfil all customer orders.

\subsection{Discussion}

The results show that competency managers in Indonesia's manufacturing companies have a significant impact on organizational performance through supply chain integration, supply chain quality and operational capability significantly in global competition. Based on the research hypothesis results, it is found that competency management affects supply chain integration (H1) is accepted. Competency manager, as indicated by the highest loading factor on computer / IT skills (loading factor 0.896 and mean 4.4733) and interpersonal skills (loading factor 0.873 and mean 4.5333), influences supply chain integration in sharing information internally and externally on the company. This study supports the research results that state that competency managers affect supply chain integration (Ellinger and Elinger, 2014; Liboni et al., 2019; Fernandez \& Jiménez, 2017; Huo, 2012; Hohenstein et al., 2014). Competency management affects supply chain quality 
(H2) is accepted. Manager's ability to use information technology and good interpersonal skills in sharing information. The ability to share internal and external company information related to product quality has been able to meet the specified specifications and help each other if there are problems encountered in supply chain management. This study supports the research results that state that competency managers affect supply chain quality (Hohenstein et al., 2014; Ellinger and Elinger, 2014; Prashar \& Aggarwal, 2020; Gunasekaran et al., 2019; Alkalha et al., 2019). Competency management affects accepted operation capability (H3). As shown by the highest loading factor on computer / IT skills and interpersonal skills, the manager's ability can increase operational capability. Competency managers can increase the company's production capacity and company planning as needed. This study supports the research results that state that competency managers affect operation capability (Yu et al., 2018; Yu et al., 2014; Shet et al., 2019; Samuelsson et al., 2016).

Supply chain integration affects supply chain quality $(\mathrm{H} 4)$ is accepted. Supply chain integration with the largest loading factor in information sharing (0.823 and mean 4.3400) and sharing forecasting (0.766 and mean 4.4133) can improve the application of quality systems to suppliers, manufacturers and customers and collaborate in solving problems at hand. Supply chain integration capabilities lead to improved quality, along with the supply chain flow. This study supports the research results that state that supply chain integration affects supply chain quality (Alkalha et al., 2019; Yu \& Huo, 2018; Soares et al., 2017; Prashar \& Aggarwal, 2020; Gunasekaran et al., 2019). Supply chain integration affects accepted operation capability (H5). The company's ability to share information and forecast with internal and external parties can increase production capacity due to reduced lead times and company planning synchronization. Supply chain integration results in good communication and collaboration, supply chain flow, and operation capability. This study supports the results of research which state that supply chain integration affects operation capability (Yu et al., 2018; Rajaguru and Matanda, 2019; Hwang \& Min, 2015; Behesti et al., 2014; Siagian et al., 2020; Chaudhuri et al., 2018; Shou et al., 2017). Supply chain integration affects increasing organization performance (H7) is accepted. Supply chain integration the company has shared information and forecasting with partners in the supply chain resulting in improved product quality. Supply chain integration also enables companies to meet customer needs in fulfilling requirements.

Supply chain quality affects accepted operation capability (H6). The supply chain quality that suppliers produce in meeting the manufacturing company's criteria has been fulfilled. The supplier has maintained the required quality, and the supplier is willing to collaborate when manufacturing quality problems are faced. According to the established plan, supply chain quality impacts the production capacity of a manufacturing company with adequate material quality. Research results support previous research, which states that supply chain quality affects operation capability (Hong et al., 2019; Yu et al., 2014; Bag et al., 2021; Yu et al., 2018). Supply chain quality directly affects operational performance (H8) is rejected. The supply chain quality that is determined is still at the stage of each role in the supply chain flow. Suppliers always pay attention to the quality required by manufacturing companies, while manufacturing companies produce products according to customer requests. The specified supply chain quality has not directly influenced organization performance due to the absence of a joint program along the supply chain. The results are different from the research results that state that supply chain quality affects operational performance (Soares et al., 2017; Hong et al., 2019; Cogollo-Flórez and Correa-Espinal, 2019). This study confirms the research results, stating that supply chain quality does not affect operational performance (Yu \& Huo, 2018).

The operation capability of the company has an impact on organization performance (H9). Operation capability, measured from the item of production capacity, planning and effective use of resources, can form adequate product quality, fulfilling requirements and the right delivery time. Operation capability can improve organization performance. This study supports previous research that states that operation capability impacts increased organization performance significantly (Yu et al., 2014; Yu et al., 2015; Yu et al., 2018; Rajaguru \& Matanda, 2019; Shet et al., 2019). The results showed that the manufacturing company's competency management was adequate so that it could have an impact on the implementation of supply chain integration and supply chain quality to increase operational capability. Supply chain integration built by manufacturing companies and suppliers and customers can improve supply chain quality, operational capability, and organization performance. This study's results provide a theoretical impact in supply chain development, especially on suppliers, manufacturers, and customers' togetherness to build supply chain performance. The results showed that the company's supply chain quality did not have a direct impact on organization performance. The flow of product quality between components in the supply chain has not been carried out in an integrated manner and synchronization between all parties in the supply chain.

\section{Conclusions and Suggestions for Future research}

The company's competitiveness is obtained by empowering all components in the supply chain. Suppliers, manufacturers, and customers in the supply chain can form a forum for communicating, coordinating, cooperating and collaborating. Based on the study results, it was found that the company's competency management with computer / IT skills and interpersonal skills was able to impact increasing supply chain integration, supply chain quality, and operation capability. Competency managers owned by manufacturing companies make an excellent contribution to the company's development in the future. Supply chain integration owned by manufacturing companies by sharing information and forecasting among components in the supply chain can impact increasing supply chain quality and operation capability. The integration that has been built 
between components can make the company in the supply chain synergy and coordinated. Supply chain quality to operation capability by implementing a sound quality system, helping each other solve quality problems and having documents that guarantee that the products produced are of high quality. Organization performance determined by operational performance in a manufacturing company is influenced by supply chain integration and operation capability. It is different from supply chain quality, which does not directly impact operation performance because the quality implementation is still carried out independently by components in the supply chain. The supplier department focuses only on the quality specified by the manufacturing company. Products produced by manufacturing companies are made following company customer specifications. Overall coordination starting from supplier, manufacture, and customer has not been done together. The company's operation performance has been able to produce quality products, fulfilling requirements and the right delivery time. This study's results provide practical contributions for manufacturing companies to improve the skills possessed by middle managers and top managers in managing supply chains. This study offers a theoretical contribution to supply chain scientific development by jointly testing the concept of competency manager, supply chain integration, supply chain quality, operation capability and organization performance. This research's limitation is that it has objects in medium and large manufacturing companies, so it is necessary to carry out an analysis of the object of study in small and micro-enterprises. Research still makes the research object are all manufacturing companies, and it needs to be focused on a type of manufacturing industry. It needs to be done in detail in implementing supply chain quality in-depth and determining its role in increasing operational performance.

\section{References}

Alkalha, Z., Reid, I., \& Dehe, B. (2019). The role of absorptive capacity within supply chain quality integration. Supply Chain Management: An International Journal, 24(6), 805-820, DOI 10.1108/SCM-10-2018-0375

Azadegan, A. (2011). Benefiting from supplier operational innovativeness: the influence of supplier evaluations and absorptive capacity. Journal of Supply Chain Management, 47(2), 49-64, doi.org/10.1111/j.1745-493X.2011.03226.x

Bag, S., Gupta, S., \& Kumar, S. (2021). Industry 4.0 adoption and 10R advance manufacturing capabilities for sustainable development. International Journal of Production Economics, 231, 107844, DOI: 10.1016/j.ijpe.2020.107844.

Behesti, H, M., Oghazi, P., Mostaghel, R., \& Hultman, M. (2014). Supply chain integration and firm performance: an empirical study of Swedish manufacturing firms. Competitiveness Review, 24(1), 20-31. doi.org/10.1108/CR-06-2013-0060

Chaudhuri, A., Boer, H., \& Taran, Y. (2018). Supply chain integration, risk management and manufacturing flexibility. Journal of Operations \& Production Management, 38(3), 690-712. doi.org/10.1108/IJOPM-08-2015-0508

Cogollo-Flórez, J.M., \& Correa-Espinal, A.A. (2019). Analytical modeling of supply chain quality management coordination and integration: a literature review. Quality Management Journal, 26(2), 72-83, doi.org/10.1080/10686967.2019.1580553

Doan, T.T.T. (2020). Supply chain management drivers and competitive advantage in the manufacturing industry. Uncertain Supply Chain Management, 8(3), 473-480, DOI: 10.5267/j.uscm.2020.5.001

Ekaterini, G. (2011). A qualitative approach to middle managers' competences. Management Research Review, 34(5), $553-575$. DOI $10.1108 / 01409171111128724$

Ellinger, A.E., \& Elinger, A.D. (2014). Leveraging human resource development expertise to improve supply chain managers' skills and competencies. European Journal of Training and Development, 38(1/2), 118-135, DOI 10.1108/EJTD-09-20130093

Fernandez, J.T., \& Jiménez, J.D.B. (2017). Supply chain integration and performance relationship: a moderating effects review. The International Journal of Logistics Management, 28(4), 1243-1271, DOI 10.1108/IJLM-02-2016-0043

Fernandes, A.C., Sampaio, P., Sameiro, M., \& Truong, H.Q. (2017). Supply chain management and quality management integration: A conceptual model proposal. International Journal of Quality \& Reliability Management, 34(1), 53-67. https://doi.org/10.1108/IJQRM-03-2015-0041

Flöthmann, C., Hoberg, K., \& Wieland, A. (2018). Competency requirements of supply chain planners \& analysts and personal preferences of hiring managers. Supply Chain Management: An International Journal, 23(6), 480-499. doi.org/10.1108/SCM03-2018-0101

Gunasekaran, A., Subramanian, N., \& Ngai, W.T.E. (2019). Quality management in the 21st century enterprises: research pathway towards Industry 4.0. International Journal of Production Economics, 207, 125-129, doi.org/10.1016/j.ijpe.2018.09.005

Hani, J.S.B. (2021). The moderating role of lean operations between supply chain integration and operational performance in Saudi manufacturing organizations. Uncertain Supply Chain Management, 9(1), 169-178, DOI: 10.5267/j.uscm.2020.10.004

Hong, J., Liao, Y., Zhang, Y., \& Yu, Z. (2019). The effect of supply chain quality management practices and capabilities on operational and innovation performance: Evidence from Chinese manufacturers. International Journal of Production Economics, 212, 227-235, doi.org/10.1016/j.ijpe.2019.01.036

Hsu, B.-M., Wang, T.-C., \& Shu, M.-H. (2020). Lot-dependent sampling plans for qualifying long-term production capability with a one-sided specification. Computers \& Industrial Engineering, 146, 106583, doi.org/10.1016/j.cie.2020.106583

Huo, B. (2012). The impact of supply chain integration on company performance: an organizational capability perspective. Supply Chain Management: An International Journal, 17(6), 596-610. doi.org/10.1108/13598541211269210

Huo, B., Qi, Y., Wang, Z., \& Zhao, X. (2014). The impact of supply chain integration on firm performance. Supply Chain Management: An International Journal, 19(4), 369-384. doi.org/10.1108/SCM-03-2013-0096

Hwang, D., \& Min, H. (2015). Identifying the drivers of enterprise resource planning and assessing its impacts on supply chain performances. Industrial Management \& Data Systems, 115(3), 541-569. doi.org/10.1108/IMDS-10-2014-0284

Kanyoma, K.E., Agbola, F.W., \& Oloruntoba, R. (2018). An evaluation of supply chain integration across multi-tier supply chains of manufacturing-based SMEs in Malawi. The International Journal of Logistics Management, 29(3), 1001-1024, DOI 10.1108/IJLM-10-2017-0277 
Liboni, L, B., Cezarino, L, O., Jabbour, C, J, C., Oliveira, B, G., \& Stefanelli, N, O. (2019). Smart industry and the pathways to HRM 4.0: implications for SCM. Supply Chain Management: An International Journal, 24(1), 124-146. doi.org/10.1108/SCM-03-2018-0150

Mabrouk, N.B. (2020). Interpretive structural modeling of critical factors for buyer-supplier partnerships in supply chain management. Uncertain Supply Chain Management, 8(3), 613-626, DOI: 10.5267/j.uscm.2020.2.002

Mello, M, H., Strandhagen, J, O., \& Alfnes, E. (2015). Analyzing the factors affecting coordination in engineer-to-order supply chain. International Journal of Operations \& Production Management, 35(7), 1005-1031. doi.org/10.1108/IJOPM-12-20130545

Mitrega, M., Frokmann, S., Zaefarian, G., \& Henneberg, S, C. (2017). Networking capability in supplier relationships and its impact on product innovation and firm performance. International Journal of Operations \& Production Management, 37(5), 577-606. doi.org/10.1108/IJOPM-11-2014-0517

Prashar, A., \& Aggarwal, S. (2020). Modeling enablers of supply chain quality risk management: a grey-DEMATEL approach. The TQM Journal, 32(5), 1059-1076.

Rajaguru, R., \& Matanda, M, J. (2019). Role of compatibility and supply chain process integration in facilitating supply chain capabilities and organizational performance. Supply Chain Management: An International Journal, 24(2), 301-316. doi.org/10.1108/SCM-05-2017-0187

Samuelsson, P., Storm, P., \& Lager, T. (2016). Profiling company-generic production capabilities in the process industries and strategic implications. Journal of Manufacturing Technology Management, 27(5), 662-691, DOI 10.1108/JMTM-06-20150042

Shet, S, V., Patil, S, V., \& Chandawarkar, MR (2019). Competency-based superior performance and organizational effectiveness. International Journal of Productivity and Performance Management, 68(4), 753-773, doi.org/10.1108/IJPPM-03-2018-0128

Shou, Y., Li, Y., Park, Y.W., \& Kang, M. (2017). The impact of product complexity and variety on supply chain integration. International Journal of Physical Distribution \& Logistics Management, 47(4), 297-317, doi.org/10.1108/IJPDLM-03-20160080

Siagian, H., Jade, K., \& Tarigan, ZJH (2020). The role of effective leadership in improving firm performance through the integrated internal system and external integration FMCG Industry. International Journal of Data and Network Science, 4(4), 365-372, DOI: 10.5267/j.ijdns.2020.9.002

Soares, A., Soltani, E., \& Liao, Y.Y. (2017). The influence of supply chain quality management practices on quality performance: an empirical investigation. Supply Chain Management: An International Journal, 22(2), 122-144, doi.org/10.1108/SCM-082016-0286

Sundram, V.P.K., Bahrin, A.S., Munir, Z.B.A., \& Zolait, A.H. (2018). The effect of supply chain information management and information system infrastructure: The mediating role of supply chain integration towards manufacturing performance in Malaysia. Journal of Enterprise Information Management, 31(5), 751-770, doi.org/10.1108/JEIM-06-2017-0084

Tan, K, C., \& Cross, J. (2012). Influence of resource-based capability and inter-organizational coordination on SCM. Industrial Management \& Data Systems, 112(6), 929-945.

Tarigan, Z.J.H., \& Siagian, H. (2021). The effects of strategic planning, purchasing strategy and strategic partnership on operational performance. Uncertain Supply Chain Management, 9(2), DOI: 10.5267/j.uscm.2021.2.006

Tarigan, ZJH, Siagian, H., Basana, SR, and Jie, F. (2019a). Effect of key user empowerment, purchasing strategy, process integration,production system to operational performance. E3S Web of Conferences 130, 01042, doi.org/10.1051/e3sconf/201913001042

Tarigan, Z.J.H., Siagian, H., \& Bua, R.R. (2019b). The impact of information system implementation to the integrated system for increasing the supply chain performance of manufacturing companies. IOP Conf. Series: Materials Science and Engineering 473, 012050, doi:10.1088/1757-899X/473/1/012050

Wang, B., Childerhouse, P., Kang, Y., Huo, B., \& Mathrani, S (2016). Enablers of supply chain integration: Interpersonal and inter-organizational relationship perspectives. Journal of Industrial Management \& Data Systems, 116(4), 838-855. doi.org/10.1108/IMDS-09-2015-0403

Yu, W., \& Ramanathan, R. (2016). Environmental management practices and environmental performance: the roles of operations and marketing capabilities. Industrial Management \& Data Systems, 116(6), 1201-1222, DOI 10.1108/IMDS-09-2015-0380

Yu, W., Ramanathan, R., \& Nath, P. (2014). The impacts of marketing and operations capabilities on financial performance in the UK retail sector: a resource-based perspective. Industrial Marketing Management, 43(1), 25-31, doi.org/10.1016/j.indmarman.2013.07.014

Yu, Y., \& Huo, B. (2018). Supply chain quality integration: relational antecedents and operational consequences. Supply Chain Management: An International Journal, 23(3), 188-206, DOI 10.1108/SCM-08-2017-0280.

Yu, W., Ramanathan, R., Wang, X., \& Yang, J. (2018). Operations capability, productivity and business performance: The moderating effect of environmental dynamism. Industrial Management \& Data Systems, 118(1), 126-143, DOI 10.1108/IMDS-02-2017-0064

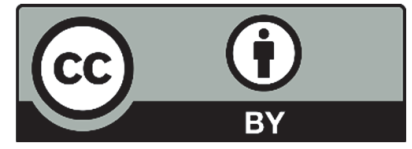

(C) 2021 by the authors; licensee Growing Science, Canada. This is an open access article distributed under the terms and conditions of the Creative Commons Attribution (CC-BY) license (http://creativecommons.org/licenses/by/4.0/). 